\title{
Obtention of Cellulose Acetate Nanofibers from Sugar Cane Bagasse
}

\author{
Obtención de nanofibras de acetato de celulosa a partir \\ del bagazo de la caña de azúcar
}

Recepción: 30 de julio de 2016

Aceptación: 06 de mayo de 2017
Andrés Felipe Ochica ${ }^{\mathrm{a}, \mathrm{d}, *}$ Efrén de Jesús Muñoz Prieto ${ }^{\mathrm{a}, \mathrm{d}}$

Ricardo Vera Graziano ${ }^{b}$

Edwin Yesid Gómez Pachón ${ }^{\mathrm{c}, \mathrm{d}}$ Alfredo Maciel Cerda ${ }^{b}$

Filiberto Rivera Torres ${ }^{\mathrm{e}}$

\begin{abstract}
Cellulose is one of the oldest natural polymers; it is renewable, biodegradable, and can be derivatized to manufacture useful products. The electrospinning, a technique for the manufacture of nanofibers, has garnered attention in recent years due to its versatility and potential for applications in various fields such as biomedicine, tissue engineering and also filtration. In this study, cellulose acetate fibers have been obtained by electrospinning. To achieve these results, the cellulose was initially obtained from the sugarcane bagasse of local plantations in Moniquira, Boyaca, then cellulose was modified to obtain cellulose acetate, which has enhanced properties for electrospinning. Yarn parameters were determined, such as needle-manifold distance, flow rate, voltage and polymer concentration, among others. Instrumental analyses were carried out including Infrared Spectroscopy (FTIR), Scanning Electron Microscopy (SEM), Differential Scanning Calorimetry (DSC), and Thermogravimetric Analysis (TGA). As a result, cellulose acetate fibers were obtained with an average diameter of $258 \mathrm{~nm}$, with excellent properties such as temperature resistance. This was done in order to continue the work on nanofiber functionalization, as for example, cationization of cellulose and further addition of reactive dyes.
\end{abstract}

Keywords: Electrospinning, Nanofibers, Bagasse, Cellulose Acetate, Cellulose.

a Escuela de Ciencias Químicas, Facultad de Ciencias básicas, Universidad Pedagógica y Tecnológica de Colombia, UPTC.

* Autor de correspondencia: efren17@gmail.com

b Instituto de Investigaciones en Materiales, Universidad Nacional Autónoma de México, Coyoacán, México, Distrito Federal.

c Escuela de Diseño Industrial, Universidad Pedagógica y Tecnológica de Colombia, UPTC, Duitama.

d Grupo de Investigación en desarrollo y nuevos materiales-DANUM, Universidad Pedagógica y Tecnológica de Colombia.

e Facultad de Química Universidad Nacional Autónoma de México, México Distrito Federal 


\section{Resumen}

La celulosa es uno de los polímeros naturales más antiguos; es renovable, biodegradable, y puede ser derivatizada para la fabricación de productos útiles. El electrohilado, una técnica para la fabricación de nanofibras, ha llamado la atención en los últimos años debido a su versatilidad y potencial para aplicaciones en diversos campos como la biomedicina,la ingeniería de tejidos y la filtración. En este estudio, se han obtenido fibras de acetato de celulosa por electrohilado. Para lograr estos resultados, la celulosa se obtuvo inicialmente a partir de bagazo de caña de azúcar de las plantaciones locales en Moniquirá, Boyacá, a continuación, la celulosa se modificó para obtener acetato de celulosa, que ha mejorado las propiedades del electrohilado. Se determinaron los parámetros de hilado, tales como la distancia aguja-colector, velocidad de flujo, la tensión y la concentración de polímero, entre otros. Análisis instrumentales se llevaron a cabo incluyendo espectroscopia infrarroja (FTIR), Microscopía Electrónica de Barrido (SEM), calorimetría diferencial de barrido (DSC), y análisis termogravimétrico (TGA). Como resultado, las fibras de acetato de celulosa se obtuvieron con un diámetro medio de $258 \mathrm{~nm}$, con propiedades excelentes tales como resistencia a la temperatura. Esta se hizo con el fin de continuar el trabajo de funcionalización de nanofibras, como por ejemplo, la cationización de celulosa y posterior adición de colorantes reactivos.

Palabras clave: electrospinning, nanofibras, bagazo, acetato de celulosa, celulosa. 


\section{Introduction}

Cellulose is by far the most abundant organic compound mainly derived from biomass. The main source of cellulose is the existing lignocellulosic material in forests, wood being considered the most important source. Other material containing cellulose may tentatively include agricultural waste, water plants and grasses. However, from the point of view of industrial marketing, cellulose, themost common biopolymer, has been used for centuriesas a raw material of trees and other plants in various applications. World production of this biopolymer is estimated between $10^{10}-10^{11}$ tonnes each year [1] and only about $6 \times 10^{9}$ tonnes is processed for paper, textile, andchemical materials [2].

Sugarcane Bagasse (SCB) is a residue generated in prominent proportions in sugar and brown sugar industries, which contains a high percentage of cellulose, can be separated from other substances, which are mainly lignin and hemicellulose [3]. Natural fibers have attracted much attention from researchers because they are inexpensive, abundant, biodegradable, renewable, strong and light weight. Cellulose fibers are valuable in a wide range of fields such as filtration and biomedical applications [4], [5].

With the Arrival of nanotechnology, cellulose began to work on this scale. Areas such as biotechnology, food, pharmaceutical, chemical, textile materials with superior properties, are an example of it [6]. Furthermore, electrospinning, a manufacturing technique of electrostatic fiber, has shown great interest because of potential applications in several fields such as tissue engineering, biosensors, filtration, wound dressing, and drug delivery and enzyme immobilization [7]. Electrospinning, is a technique in which polymeric solutions are made with substances with high dielectric constants, with which can be obtained nanoscale fibers with various compounds such as chitosan, starch, cellulose acetate, polylactic acid (PLA),among others.

Cellulose acetates are obtained treating cellulose with a mixture of acid and acetic anhydride, in the presence of catalysts such as sulfuric acid, hydrochloric acid, phosphoric acid, zinc chloride, etc. or electrolytes that promote the formation of compounds of adding cellulose. However, the reactions require a very long time [8-10]and the energy consumption is high. The synthesis by microwave represents an alternative technique to provide thermal energy to the reaction with interesting advantages such as time savings and energy, generating fewer BY-products, the optimization of yields, obtaining productsin a smaller number of steps, without counting that is an alternative that supports the development of new lines of research through the optimization of conditions [11].

In this study, cellulose acetate fibers were generated by electrospinning, using equipment developed at the Pedagogical and Technological University of Colombia in the DANUM group, this allowed different types of nanoscale fibers to be obtained, with different substances such as chitosan, starch acetate, cellulose, polylactic acid (PLA), among others; It also allowed finding the optimal processing parameters (concentration, tension, flow out and away from the needle to the collector) that affect the final product quality[21-22] .

\section{Materials and Methods}

Sodium hydroxide, $\mathrm{NaOH}$ (Emsure, 99\%) was used for purification of cellulose, Nitric Acid, HNO3 (Merck, 65\%), Ethanol, EtOH (Sigma-Aldrich, 99.8\%) was also used this was done in an oven (MLW WSO 
$100 \mathrm{S1086);} \mathrm{for} \mathrm{the} \mathrm{synthesis} \mathrm{of} \mathrm{Cellulose}$ Acetate (AC) Resublimed Iodine (Carlo Erba, 99.9\%), Acetic Anhydride, AA (Merck, 98.5\%) and Microwave equipment (SINEO MDS-8G, No. was used Ref 08G086M).; for electrospinning an equipment of high voltage source (HV350R), Injector Pump Systems Inc NE-1000, a copper collector, covered with aluminum, plastic needles $10 \mathrm{ml}$ mark Plasticak a capil-lary diameter as used $0.8 \mathrm{~mm}$. Electrospinning equipment was developed and built in the Pedagogical and Technological University of Colombia (UPTC) in a group: Development and Application of New Materials (DANUM). To prepare the electrospinning polymer solution, $\mathrm{N}$-dimethyl formamide, DMF (Panreac, 99.8\%) and acetone, Ac (Panreac, 93.5\%) were used as solvents .The bagasse from sugar cane was obtained in the town of Moniquirá (Boyacá, Colombia). All chemicals were of analytical grade, purchased from Representante de Productos Químicos(Bogotá, Colombia).The commercial cellulose acetate was obtained from Alldrich Chemical Company, and used without further purification.

Purification: Purification of the sugarcane bagasse (SCB) was obtained in a laboratory following the methodology proposed by Rodrigues Filho et al. [9]. A mixture of 754 $\mathrm{mL} \mathrm{NaOH}(0.25 \mathrm{M})$ and $4 \mathrm{~g}$ of dry, ground bagasse was kept at room temperature for 184 $\mathrm{h}$. Then, this mixture was filtered and washed with distilled water. Next, the bagasse was refluxed with a $\mathrm{HNO} 3 /$ ethanol solution $(20 \%$ $\mathrm{v} / \mathrm{v}$ ) for $34 \mathrm{~h}$, with the alcoholic solution being changed at $14 \mathrm{~h}$ intervals. After the reflux, the bagasse was washed with distilled water and oven dried at $1054 \mathrm{C}$ for $64 \mathrm{~h}$.

Acetylation: Acetylation of SCB cellulose was obtained in a laboratory using the methodology proposed by Rodrigues Filho et al. [10], with some modifications.

Electrospinning: Two types of fibers were made, one with the SCB cellulose acetate and another with Aldrich cellulose acetate, using the electrospinning equipment of the Pedagogical and Technological University of Colombia, adapting Khatri's methodology [14] at a concentration of $17 \% \mathrm{w} / \mathrm{v}$ with the following modifications:

Infrared Spectroscopy (FTIR): IR spectra of cellulose and cellulose acetate (CA) were obtained with IS50 NICOLET FT-IR, using the ATR method.

SEM Scanning Electron Microscopy: The morphology of the fibers was examined on a SEM-JSM-7600F JEOL, at the Institute for Materials Research of the Na- tional Autonomous University of Mexico (UNAM); the data was processed using the "Imagej" program.

Differential Scanning Calorimetry (DSC): DSC anal- ysis was carried out on a DSC

Table 1. Electrospinning Parameters.

\begin{tabular}{ccc}
\hline & $\begin{array}{c}\text { Cellulose acetate from SCB } \\
\text { Parameters }\end{array}$ & $\begin{array}{c}\text { Cellulose acetate from Aldrich } \\
\text { Parameters }\end{array}$ \\
\hline $\begin{array}{c}\text { Distance from Injec- tor to } \\
\text { Collector }\end{array}$ & $15 \mathrm{~cm}$ & $15 \mathrm{~cm}$ \\
\hline Potential & $15 \mathrm{KV}$ & $15 \mathrm{KV}$ \\
\hline Solution Injection Speed & $0,3 \mu \mathrm{L} / \mathrm{h}$ & $90 \mu \mathrm{h} / \mathrm{h}$ \\
\hline Capillary Diameter & $0,4 \mathrm{~mm}$ & $0,4 \mathrm{~mm}$ \\
\hline Solvent 2:1 & Acetone/DMFA & Acetone/DMFA \\
\hline
\end{tabular}


Q2000 V24.10 Build 122, DSC Module Standard Cell RC, located at the Institute for Materials Research at UNAM. Treatment of the results was performed using Universal Analysis 2000 software by TA Instruments.

TGA Thermogravimetric Analysis: Fibre analysis was carried out on a TGA Q5000 V3.15 Build 263 Module TGA. The data results were processed using Universal Analysis 2000 software by TAInstruments.

\section{Results and Discussion}

Infrared Spectroscopy (FTIR): Figure 1, showing the spectra of purified cellulose bagasse sugarcane, it can be seen that the purification was carried out successfully because of the comparison with the infrared spectrum of Contreras et al. [15] as well as acetylated cellulose (cellulose acetate); the presence of a band was observed at 1734.94 $\mathrm{cm}^{-1}$, attributed to the stretching vibration of the carbonyl group; this band is not present in the spectrum of the cellulose since it is characteristic of an acetylated material; reduction is also observed in the intensity of the band at $3322.5 \mathrm{~cm}^{-1}(\mathrm{OH}$ stretch), concluding that the reaction occurred [8].

Scanning Electron Microscopy-SEM: In figure 2, SEM micrographs seen at 1000x and $10000 x$; we see that the nanofibers from the SCB cellulose acetate are of a uniform, cylindrical structure; while drops in the fibers (clusters) can be seen in the Aldrich cellulose nanofibers: this is mainly due to the lower flow rate of the injector pumping the polymer with the BCA cellulose acetate when compared with Aldrich's; This could lead to the conclusion that a lower flow rate results in thinner fibers, and this is comparable with what is observed in the literature [16-20]. As for the fiber size, average sizes are: cellulose ac- etate BCA $258 \mathrm{~nm}$ with $\mathrm{SD}=$ $0.123 \mathrm{~nm}$; Aldrich cellulose acetate $448 \mathrm{~nm}$ with SD $=0.410 \mathrm{~nm}$ (See Figure 3).

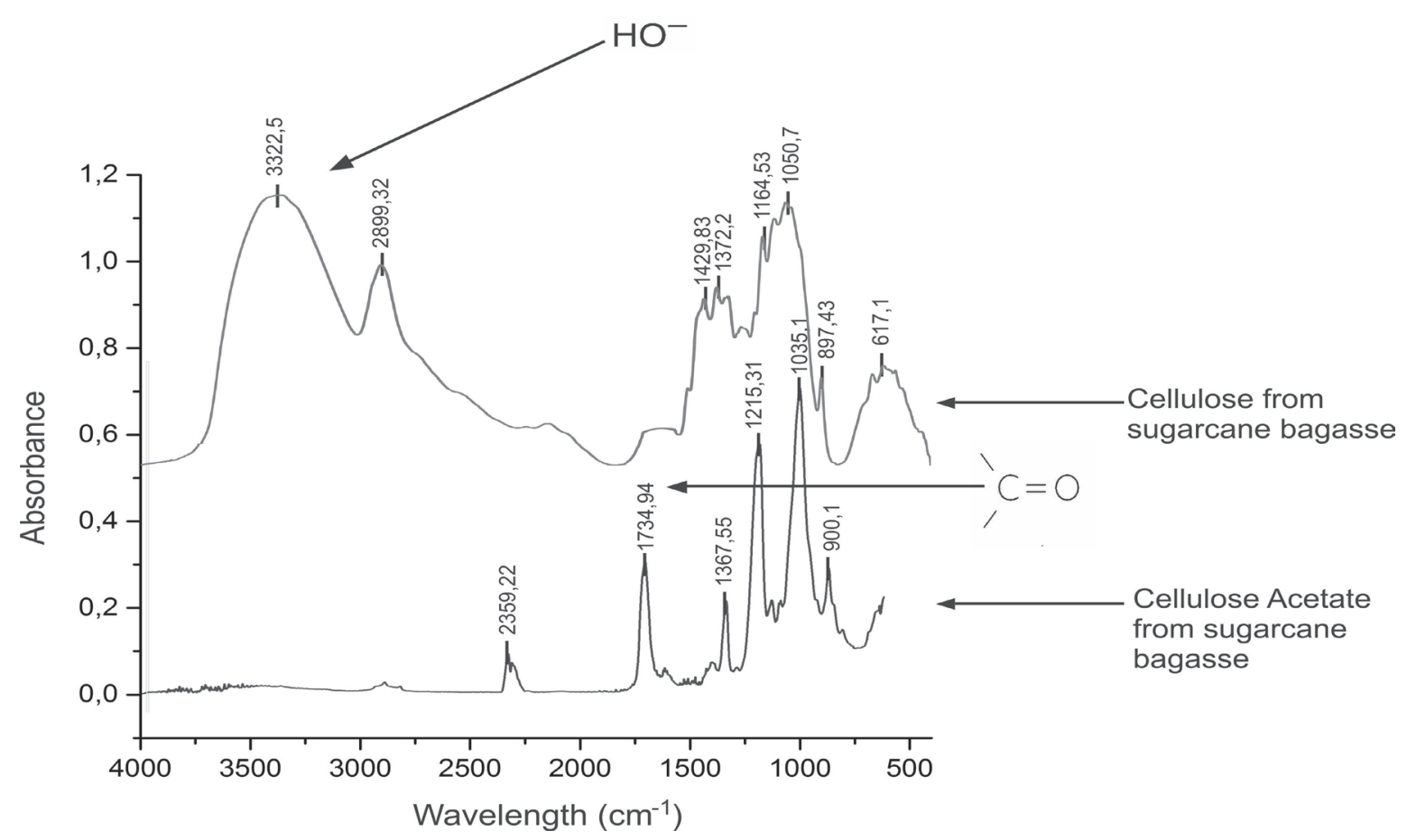

Figure 1. SCB cellulose and Cellulose acetate IR Spectra. 


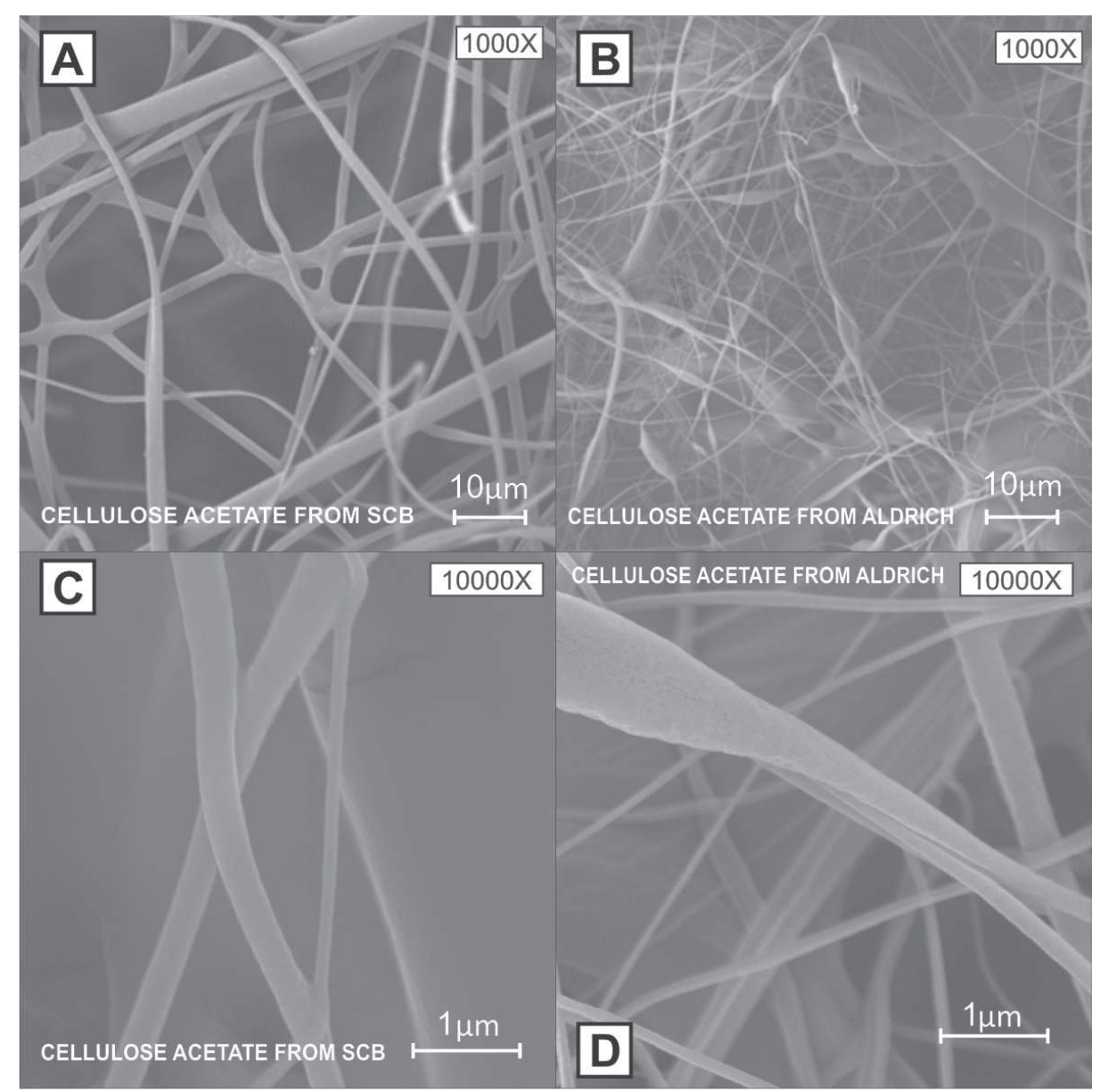

Figure 2. A) and C) SCB Cellulose acetate micrographs; B) and D) Aldrich cellulose acetate micrographs.
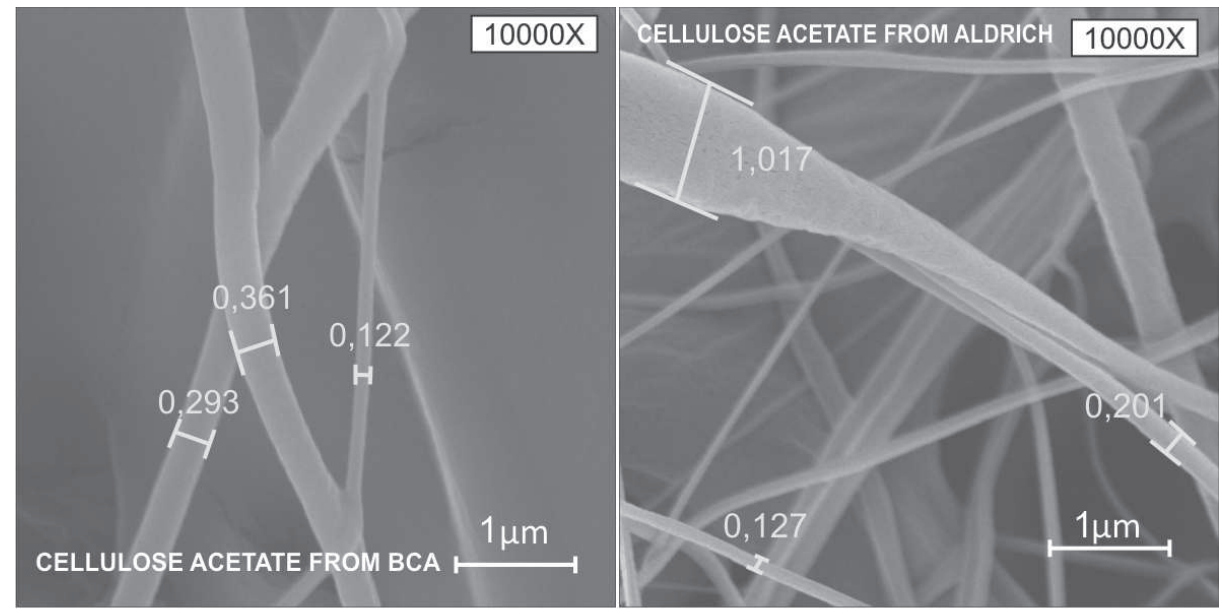

$$
\begin{gathered}
\dot{x}=0,258 \mu m=258 \mathrm{~nm} \\
S D=123 \mathrm{~nm}
\end{gathered}
$$

$$
\begin{gathered}
\dot{x}=0,448 \mu m=448 \mathrm{~nm} \\
S D=410 \mathrm{~nm}
\end{gathered}
$$

Differential Scanning Calorimetry - DSC: Table 2 summarizes DSC performance of Aldrich cellulose ac- etate compared to DSC of cellulose acetate from sugar cane bagasse. Enthalpy relaxation corresponding to sol- vent evaporation can be observed, the exothermic curve corresponding to a crystallization temperature and a fur- ther enthalpy relaxation corresponding to the materialmelting. 


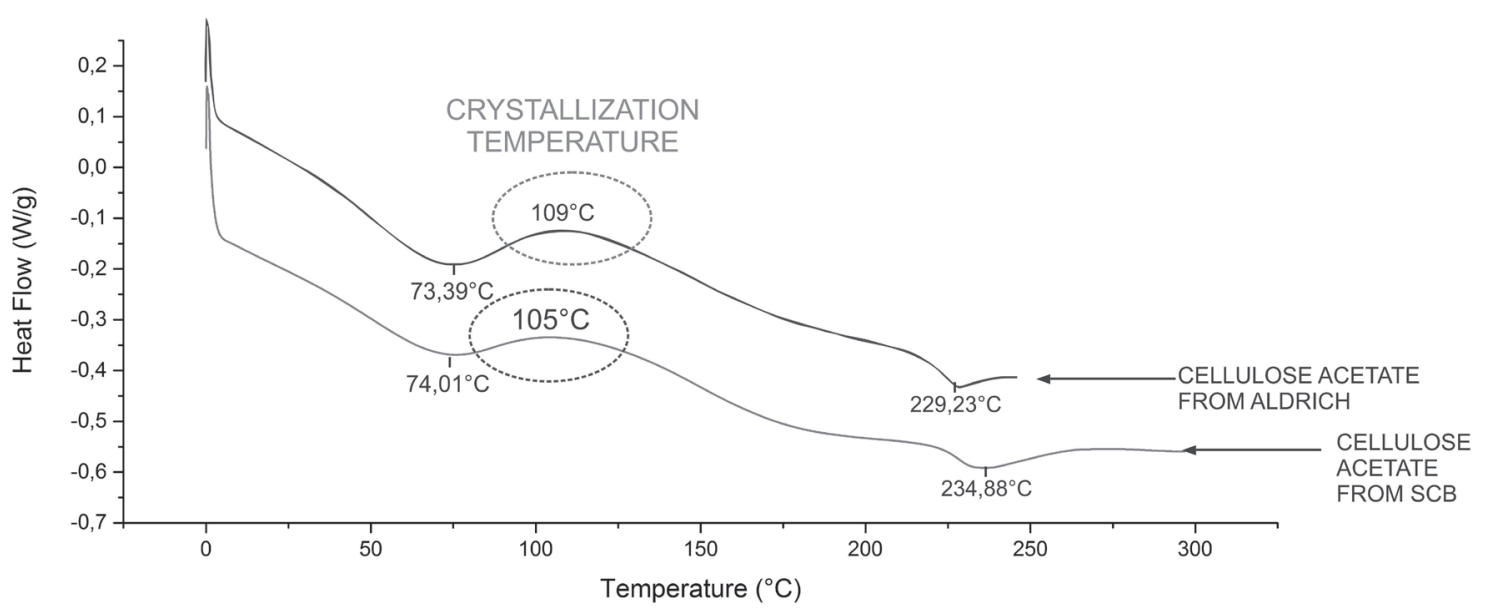

Figure 4. DSC for Aldrich cellulose acetate and BCA cellulose acetate.

As can be seen, the crystallization temperature in the SCB cellulose acetate is lower, probably due to the smaller diameter of the nanofibers making it much easier to reach the crystallization point; The same happens with the melting point, which in the case of the SCB is also higher, given that melting resistance is higher the smaller the diameter of the fibers.

Table 2. DSC results summary.

\begin{tabular}{|l|l|}
\hline DSC SCB & DSC Aldrich \\
\hline Evaporating Temperature: & Evaporating Temperature: \\
$74,01^{\circ} \mathrm{C}$ & $73,39^{\circ} \mathrm{C}$ \\
\hline Crystallization: $105^{\circ} \mathrm{C}$ & Crystallization: $109^{\circ} \mathrm{C}$ \\
\hline Melting Point: $234,88^{\circ} \mathrm{C}$ & Melting Point: $229,23^{\circ} \mathrm{C}$ \\
\hline
\end{tabular}

Cellulose Acetate from Aldrich

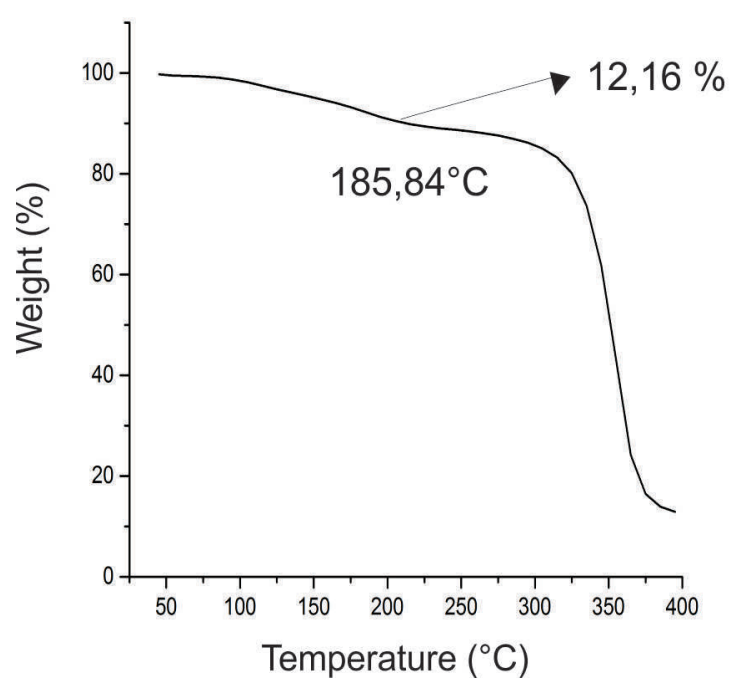

Cellulose Acetate from SCB

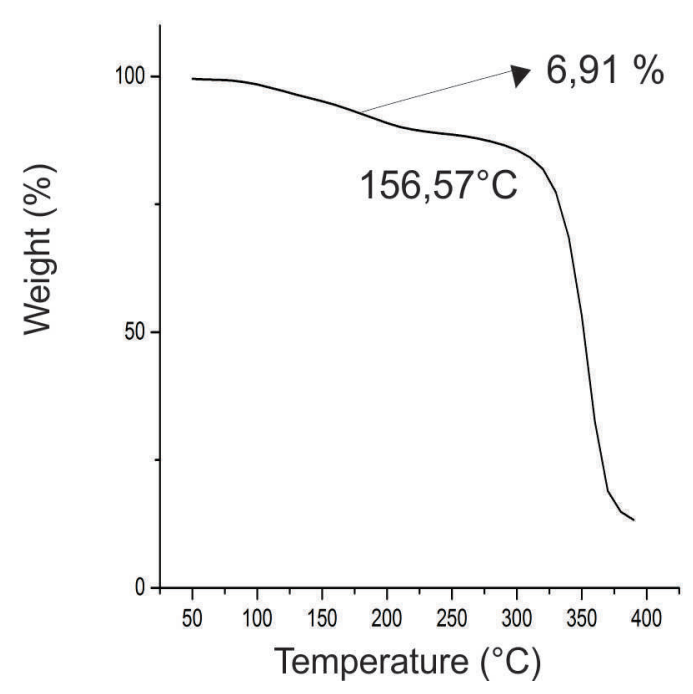

Figure 5. TGA Cellulose Acetate from Aldrich TGA CelluloseAcetate from SCB. 
Thermogravimetric Analysis (TGA): With the TGA we can observe the mass loss versus temperature in the case of cellulose acetate SCB, with a loss of mass of $12.16 \%$, corresponding to the retained solvents and ad-sorbed moisture; in the case of Aldrich cellulose acetate, the percentage of loss of these solvents is lower, at $6.911 \%$; this may be because the cellulose acetate fiber of the $\mathrm{SCB}$, being thinner, adsorbs more moisture and this may be due to the greater porosity of the material. This test is complementary to the DSC, as when the mass is completely decreasing it is due to the material being degraded; said degradation starts after melting, as seen in Table 2.

\section{Conclusions}

FTIR analysis confirmed the production of cellulose acetate synthesis from the cellulose of natural sugar bagasse. Cellulose acetate nanofibers were successfully obtained by electrospinning technique, with an average diameter of $258 \mathrm{~nm}$ from the bagasse of sugar cane. By minimizing the injection rate, we obtained finer fibers without clusters and with better properties. Cellulose acetate from sugarcane bagasse is comparable with that from the Aldrichbrand, according to the DSC and TGA.TGA presents loss between $325^{\circ} \mathrm{C}-390^{\circ} \mathrm{C}$ this is due to a phenomenon of fusion of cellulose derivative. On the basis of the charac- terization we should use this nanofibers as a material for biofilters.

\section{References}

[1] M. Ahmed, S. Azizi, F. Alloin, and A. Dufresne, "Review of Recent Research into Cellulosic Whiskers, Their Properties and Their Application in Nanocomposite Field," pp. 612-626, 2005.

[2] J. Simon, H. P. Miller, R. Koch, and V. Miiller, "Thermoplastic and biodegradable polymers of cel- lulose", vol. 3910, no. 97, pp. 107-115, 1998.
[3] W. Sn, "Sugarcane Bagasse: How Easy Is It to Mea- sure Its Constituents?", pp. 266273, 2008.

[4] A. Awal, S. B. Ghosh, and M. Sain, "Development reinforced biocomposite fibers," J. Mater. Sci., no. June, pp. 28762881, 2009.

[5] A. Alemdar and M. Sain, "Biocomposites from wheat straw nanofibers?: Morphology, thermal and mechanical properties," Compos. Sci. Technol., vol. 68, pp. 557-565, 2008.

[6] D. Klemm, F. Kramer, S. Moritz, T. Lindström, M. Ankerfors, D. Gray, and A. Dorris, "Nanocelluloses: A New Family of Nature-Based Materials," Angew. Chemie Int. Ed., pp. 5438-5466, 2011.

[7] N. Bhardwaj and S. C. Kundu, "Electrospinning?: A fascinating fiber fabrication technique," vol. 28, pp. 325347, 2010.

[8] D. A. Cerqueira, G. R. Filho, and C. da S. Meireles, "Optimization of sugarcane bagasse cellulose acety- lation," Carbohydr. Polym., vol. 69, pp. 579-582, 2007.

[9] G. Rodrigues, S. Francelino, D. Pasquini, D. Alves, $X$ De Souza, and R. Nascimento, "Water flux through cellulose triacetate films produced from het- erogeneous acetylation of sugar cane bagasse," J.Memb. Sci., vol. 177, pp. 225$231,2000$.

[10] G. Rodrigues, D. Santos, C. da S. Meireles, R. Nasci- mento, D. A. Cerqueira, H. Barud, S. Ribeiro, and Y. Messadeq, "Synthesis and characterization of cel- lulose acetate produced from recycled newspaper," Carbohydr. Polym., vol. 73, pp. 74-82, 2008.

[11] J. Li, L. Zhang, F. Peng, J. Bian, T. Yuan, F. Xu, and R. Sun, "Microwave-Assisted Solvent-Free Acety- lation of Cellulose with Acetic Anhydride in the Presence of Iodine as a Catalyst," Molecules, pp. 3551-3566, 2009.

[12] R. Konwarh, N. Karak, and M. Misra, "Electrospun cellulose acetate 
nanofibers: The present status and gamut of biotechnological applications," Biotechnol. Adv., vol. 31, no. 4, pp. 421437, 2013.

[13] S. Demirci, A. Celebioglu, and T. Uyar, "Sur- face modification of electrospun cellulose acetate nanofibers via RAFT polymerization for DNA ad-sorption," Carbohydr. Polym., vol. 113, pp. 200-207, 2014,

[14] Z. Khatri, G. Mayakrishnan, Y. Hirata, K. Wei, and I. Kim, "Cationic-cellulose nanofibers?: Preparation and dyeability with anionic reactive dyes for apparel application," Carbohydr. Polym., vol. 91, no. 1, pp. 434-443, 2013.

[15] H. Contreras, H. Trujillo, G. Arias, J. Pérez, and

E. Delgado, "Espectroscopia Atr-Ftir De Celulosa?: Aspecto Instrumental y Tratamiento Matemático De Espectros," e-Gnosis, vol. 8, pp. 1-14, 2010.

[16] L. M. Duque Sánchez, L. Rodriguez, and M.López, "Electrospinning?: la era de las Nanofibras," Rev. Iberoam. Polímeros, vol. 14, no. 1, pp. 10-27, 2014.

[17] E. d. J. M. Prieto, B. Rivas, and J. Sánchez, "Natural polymer grafted with syntethic monomer by microwave for water treatment-a review," Ciencia en Desarrollo, vol. 4, pp. 219-240, 2013.

[18] Y. C. Cárdena-Pérez, R. Vera-Graziano, E. d. J. Muñoz-Prieto, E. Y. GómezPachón, "Obtención y caracterización de andamios electrohilados a base de quitosano y fibroína del capullo (Bombyx
mori)"IngenieríaY Competitividad, Vol. 19, No. 1, pp. 134 - 146, 2017.

[19] Á. P. Sánchez-Cepeda, R. Vera-Graziano, E. de J. Muñoz-Prieto, E. Y. GómezPachón, M. J. Bernad-Bernad, A. MacielCerda., "Preparación y caracterización de membranas poliméricas electrohiladas de policaprolactona y quitosano para la liberación controlada de clorhidrato de tiamina" "Ciencia en Desarrollo," Vol. 7 No. 2, pp. 133-151, 2016.

[20] Í. G. Ramírez and E. de jesus de Jesús Muñoz, "Desarrollo de un sistema de filtración utilizando materiales sinterizados como medios filtrantes," Ingenio Magno, vol. 7, pp. 43-55, 2016.

[21] J. Sanchez, L. Toledo, B. L. Rivas, N. Rivera, and E. Munoz, "Watersoluble cationic cellulose coupled to a ultrafiltration membrane for the removal of arsenic and chromium," Journal of the Chilean Chemical Society, vol. 58, pp. 1986-1990, 2013.

[22] Rúa Jiménez S.L., Villate Lagos J.D., Gómez-Pachón E.Y., Torres Perez Y., Muñoz Prieto E. (2017) Development of an Equipment to Prepare Nanofibers for Tissue Engineering Since a Standpoint of the Industrial Design. In: Torres I., Bustamante J., Sierra D. (eds) VII Latin American Congress on Biomedical Engineering CLAIB 2016, Bucaramanga, Santander, Colombia, October 26th -28th, 2016. IFMBE Proceedings, vol 60. Springer, Singapore 